\title{
ОСОБЛИВОСТІ ПІДВИЩЕННЯ ЯКОСТІ ПІДГОТОВКИ ВИКЛАДАЧІВ НА КАФЕДРІ НЕЙРОХІРУРГІЇ І НЕВРОЛОГІЇ ОДЕСЬКОГО НАЦІОНАЛЬНОГО МЕДИЧНОГО УНІВЕРСИТЕТУ
}

\author{
А. С. Сон, В. В. Добровольський, Г. В. Перькова \\ Одеський національний медичний університет
}

\begin{abstract}
FEATURES OF IMPROVEMENT THE QUALITY OF TEACHERS TRAINING AT THE DEPARTMENT OF NEUROSURGERY AND NEUROLOGY ODESA NATIONAL MEDICAL UNIVERSITY
\end{abstract}

\author{
A. S. Son, V. V. Dobrovolskyi, H. V. Perkova \\ Odesa National Medical University
}

\begin{abstract}
У статті представлений аналіз методичних підходів, запропонованих кафедрою нейрохірургії і неврології Одеського національного медичного університету, щодо підвищення якості підготовки викладачів. Нові підходи до поєднання наукової, викладацької, виховної діяльності висувають серйозні вимоги до викладача, який для підвищення якості своєї роботи повинен багато працювати над своєю майстерністю при допомозі кафедри та університету.
\end{abstract}

The article presents the analysis of methodological approaches proposed by the Department of Neurosurgery and Neurology Odesa National Medical University, to improve the quality of academic and clinical work. New approaches to combining research, teaching, educational activities impose severe demands on the teacher, which is to improve the quality of their work needs a lot of work on their skills with the help of the department and the university.

Вступ. В період реформування медицини в нашій країні, коли на студентську молодь впливає злива різноманітної інформації, виникають конкурентна боротьба та проблеми з працевлаштуванням. В цих умовах на перший план в мотивації навчання виходить авторитет університетського викладача, за допомогою якого можливо привести знання студента у відповідну систему, використовуючи яку, молодий спеціаліст зміг би витримати серйозну конкуренцію на ринку медичних послуг.

Як свідчать соціологічні дослідження, більшість студентів розглядає особистість викладача як поєднання лікаря високого рівня медичної кваліфікації, вихователя й вимогливої, авторитетної особистості.

“... медик, історик, філолог, - писав К. Д. Ушинський, - можуть принести безпосередньо користь справі вихователя тоді, коли вони не тільки спеціалісти, а й педагоги ..." [1].

Студенти цінують творчість вчителя, наявність у нього почуття нового, його вміння відступати від визначених педагогічних шаблонів. Вони не люблять сірості і одноманітності, засуджують необ' єктивність, відсутність єдності і в словах, і в діях, і особливо -

(C) А. С. Сон, В. В. Добровольський, Г. В. Перькова завищені вимоги до учня при поверхньому знанні предмета самим викладачем [2].

Але реформування медицини, нові вимоги до якості роботи лікаря, ставлять нові завдання перед викладацьким складом кафедри й керівництвом університету для покращення якості навчального процесу, і в першу чергу за рахунок нових підходів до підготовки самих викладачів.

Основна частина. Умовно молодих викладачів можно розділити на три групи.

Перша група досить невелика, поєднує в собі навички лікаря, науковця й педагога. Вони більш вміло подають студентам знання під кутом громадської позиції, що особливо важливо в сучасному громадському житті. Такі викладачі, які виходять на передові рубежі науки, здійснюють творчий підхід до аудиторії, стають взірцем для студентів і отримують найкращі результати у своїй роботі. Деякі молоді викладачі мають схильність до наукової роботи, але цього недостатньо з точки зору педагогіки, на якість викладання також впливають природні дані. Педагогічні навички такого викладача, а також робота над собою можуть покращити якість навчального процесу. Звісно, на нашу думку, цю проблему бажано вирішувати на рівні формування кафедри, ліквідувати недо- 
ліки під час навчання в інтернатурі та опанування асистентської посади.

Друга група - це молоді викладачі, які не повною мірою приділяють увагу науковій праці, але добре володіють педагогічними прийомами та присвячують себе лише практичній лікарській роботі. 3 часом вони відчувають брак знань. Нові умови вимагають від них глибокого проникнення в зміст нових відкриттів у науці. Саме життя й спілкування 3 сучасними студентами вимагають від них постійної роботи над своїми знаннями. Ця категорія викладачів потребує постійної уваги керівників кафедри та університету.

До третьої групи належать випадкові люди на ниві підготовки студентів. В них відсутні глибокі знання педагогіки. Ці викладачі маскують педагогічність підвищеною вимогливістю, що негативно впливає на процес навчання.

Які ж напрямки роботи у вирішенні проблем, пов'язаних з підвищенням якості відбору та підготовки викладачів, впроваджуються в університеті, безпосередньо на кафедрі.

Важливу роль відіграє низка організаційних заходів. Для вирішення питань якісної підготовки до занять використовується тісний контакт кафедри з деканатом, старостатом і взагалі з широкою громадськістю університету.

Матеріали, які необхідні для проведення занять, є у вільному доступі в університетській бібліотеці (на Інтернет-сайті в електронному варіанті також) та безпосередньо на кафедрі. Перед тим як почати курс лекцій, на кафедрі проводиться семінар з участю представників деканату й студентського активу, де обговорються питання подолання мовного бар'єра, вивчаються особливості менталітету слухачів, якість опанування матеріалу, релігійні особливості студентських груп. Важливо підкреслити, що в семінарі беруть участь не тільки студенти, але й усі учасники процесу навчання (лаборанти, інтерни, аспіранти, асистенти, доценти). Крім того, серйозну допомогу викладачам надають відкриті лекції та їх обговорювання, де головними критеріями є не тільки професійна підготовка, але й впровадження в життя елементів виховання, вміння найти контакт з аудиторією. Керівництво кафедри вимагає роботи з підвищення педагогічної майстерності ретельно планувати та контролює виконання практичного її виконання. Під час методичних нарад кафедри акцентується увага на пов' язання виховного процесу з якісним вирішенням професійних завдань.

Вміння поєднувати високий професіоналізм під час викладання курсу нервових хвороб з високою мето- дичною майстерністю, клінічною роботою для опанування практичних навичок студентів під час їх находження на кафедрі, з виховним процесом дає позитивний результат, формуючи у студента ті якості, які необхідні йому в практичній лікарській діяльності, спроможні підвищити його авторитет і здатність спілкування з пацієнтом.

Моральний авторитет викладача має бути бездоганним не тільки під час спілкування з учнями, а й у повсякденному житті [3].

Ми провели опитування студентів, після завершення навчання на кафедрі, щодо їхньої загальної оцінки викладачів. Більшість студентів звертала увагу на виконання викладачем моральних і етичних норм поведінки (47\%), в другу чергу-на його професійні якості (34 \%), й в третю чергу - на зовнішній вигляд (19\%).

Особливо зростає значення морального виховання в умовах ринкових відносин. Дотримання слова, пошана до медичного персоналу й хворих, до результатів чужої праці, неприйняття пустодзвонства, демагогії- ось декілька якостей, які формує викладач у студентів.

При підготовці до зустрічі зі студентами на кафедрі ретельно готуються. Для якісного проведення лекцій, практичних занять попередньо вивчається склад груп студентів. Дуже важливо знати їх соціальний та національний склад, з якої місцевості вони прийшли в університет, при цьому ми намагаємось 3'ясувати, ким встигли попрацювати студенти до університету. Треба сказати, що в університеті вже намітилось розмежування в соціальному плані, у студентів різний підхід до навчання, він також проявляється у студентів, які вчаться як за державним замовленням, так і за контрактом. Всі ці фактори впливають на якість сприяння матеріалу, тому дуже важливо, щоб викладач зумів знайти підхід до кожного зі студентів.

Ретельної роботи вимагає робота з закордонними студентами. Дуже важливу роль відіграє те, як викладач знає суспільно-політичний стан, елементи культури, менталітет мешканців країни, з якої прибув іноземний студент. Під час роботи зі студентамиіноземцями це дає можливість диференційовано підійти до кожного. Обізнаність викладача в особливостях країни студента-іноземця піднімає авторитет викладача, а значить якість навчального процесу. Багато громадян африканських країн мають досить великий мовний бар'єр, погано знають англійську мову, якою ведеться викладання на кафедрі. Під час практичних занять важливий аспект має спілкування викладача 3 хворими та медперсоналом, правильність та охайність спеціального одягу, дуже важливу роль відіграє зовнішність викладача. Велике 
значення мають знання мови викладачем, його дикція та вміння логічно довести матеріал до слухачів. Головне, на що наголошують іноземні студенти, це практичне освоєння матеріалу й тому достатньо вимогливі до викладача.

Хотілось би також підкреслити, що на кафедрі уважно ставляться до релігійних уподобань студентів. Врівноважене, підкреслено шанобливе ставлення до тієї чи іншої релігії, знання релігійних свят, деяких обрядів викликають повагу до викладача і значно покращують процес навчання.

Важливу роль відіграє використання викладачем повною мірою технічних засобів. Це є підготовчий функціональний компонент, направлений через суб'єкта одного з учасників навчальної діяльності, самого викладача. Цей компонент має велике значення для підвищення якості навчальної діяльності. В організаційно-методичному відділі університету забезпечують підготовку викладачів, в першу чергу пов'язану з педагогічною діяльністю і підготовкою до занять $з$ використанням технічних засобів навчання й виховання, де складовими елементами педагогічної майстерності є ораторське мистецтво та безпосередньо медична практика.

Залежно від конкретної мети використовується обладнання. Головна тактична мета забезпечення поточної підготовки викладача до занять - це аналіз інформації, що отримана від деканату, щодо якісного складу груп під час підготовки до зустрічі з конкретними студентами: національність, менталітет, якість навчання з інших дисциплін тощо.

\section{Література}

1. Ушинський К. Д. Вибрані педагогічні твори / К. Д. Ушинський. -К. : Радянська школа, 1949. - С. 418.

2. Сухомлинський В. О. Розмова з молодим директором / В. О. Сухомлинський // Вибрані твори : в 5 т. / В. О. Сухомлинський.-К. : Радянська школа, 1977.-Т. 4.-С. 393-622.
Більш стратегічна мета - підвищення загального рівня педагогічних знань викладача. Ці знання використовуються також для читання лекцій на суміжних кафедрах, пробних лекцій при заміщені вакантних посад, для семінарів з наукової діяльності, організації навчального процесу.

Висновки. Таким чином, головними напрямками підвищення якості підготовки викладача є:

- якісний відбір на кафедру викладачів, які зможуть поєднати в собі наукову, лікарську діяльність та педагогічний підхід до навчання;

- навчання студентів морально-етичних норм поведінки;

- створення умов для наукової роботи та підвищення педагогічної майтерності викладачів організаційними методами кафедри та університету;

- находження взаємодії з аудиторією за рахунок диференційованого підходу до кожного студента шляхом попереднього вивчення менталітету слухачів (особливо студентів-іноземців).

На перший план роботи з підвищення якості підготовки виходить особистість викладача і в першу чергу -це виконання викладачем моральних і етичних норм поведінки, в другу чергу - його професійні якості, й в третю чергу - зовнішній вигляд.

Нові підходи до поєднання наукової, викладацької, виховної діяльності висувають серйозні вимоги до викладача, який для підвищення якості своєї роботи повинен багато працювати над своєю майстерністю, використовуючи досвід, можливості допомоги кафедри та університету.

3. Ушинський К. Д. Людина як предмет виховання / К. Д. Ушинський // Історія української школи і педагогіки. Хрестоматія / за ред. В. Г. Кременя. - К. : Знання, 2005. C. 237-246. 